\title{
Islamic Society and State Power in Senegal
}

By Leonardo A. Villalón. Cambridge: Cambridge University Press, $1995, \mathrm{pp} .338$.

Senegal is one of the most stable sub-Saharan African countries. Leonardo Villalon's book, Islamic Society and State Power in Senegal, attributes that stability to the forms of religious organization provided by Senegal's unique brands of Sufism. Most Senegalese are affiliated to a marabout (Sufi leader) and are members of a Senegalese Sufi order. These orders remain the most pervasive forms of social organization. Leonardo Villalón's work, devoted to an examination of the shape of Senegalese society, therefore focuses on its most salient feature: the forms and patterns of its religious organization.

The author argues that the Senegalese Sufi orders, developed in the wake of French colonialism, provide an effective mode of social organization vis-à-vis the state. They check the hegemonic ambitions of the state and give a measure of leverage to the isciple-citizens in their dealings with it. This maraboutic system explains much of Senegal's relative success in maintaining a dynamic balance between state and society. In other words, the Sufi pattern has become the basis for the establishment of a religiously based "civil society." While this balance remains precarious, as there are conceivable factors that can disrupt it, it has thus far shielded Senegal from the instability and strife that continue to bedevil many African societies. 
The book is based on empirical research focusing on the town of Fatick, a regional administrative center. Fatick is the prism through which the author examines the theoretical issue of how Islam has an impact on the relationship between state and society in Senegal. Departing from an essentialist approach to the political role of Islam, his approach is context specific, focusing less on Islam as theology or ideology than on Islam as social organization.

The work relies on the wealth of existing research in the fields of African state-society relations, Islam and politics, and on Senegal itself. Through this multidisciplinary approach Leonardo Villalón hopes to contribute to the integration of "these islands of research as a means of contributing to the development of theoretical propositions in each."

The work is divided into seven chapters. The first chapter summarizes the theoretical issues and defines the nature of African states. Chapter 2 provides relevant background information in the local context. In it he explores the complexity of the ethnic and caste systems in Senegal, and the concept of a "deep Sahelian culture." He also explains why neither the ethnic nor the caste systems function as a basis for political action. The chapter also explores the origins and evolution of Senegambian Islam, with special focus on the Sufi orders and their founding fathers.

While the author emphasizes the centrality of the orders in state-society relations, he mentions two challenges to their supremacy: the "arabisants," who are mostly young men educated in institutions in the Arab world, and Westernized intellectuals who advocate secularism. In discussing the patterns of interaction between state and local populations, the centralized character of the Senegalese state structure receives special attention. Citizens, prevented by the vagaries of agriculture in the Sahel from developing structures of economic self-reliance, are bound to cooperate with the subsidizing state.

Chapters 4 and 5 explore the other dimension of state-society relations by looking into the marabout-disciple relationship. An examination of the incentives for both followers and leaders (tälibées-marabouts) to maintain long-term ties explains the stability of the maraboutic system. Also explored in these chapters are the rituals and social structures that maintain and reinforce the relationship, as well as their limits. By analyzing state-marabout relations in chapter 6 , the author delineates the general patterns of interaction between the religious and the political elite in Islam.

Chapter 7 analyzes the precarious balance between the three sets of players: bureaucrats, marabouts, and citizen-disciples. This analysis includes an explanation for the success of the original charismatic movements, which gave rise to the contemporary orders. Also, the examination of a recent maraboutic movement, which has thus far adopted the isolationist mode in its relationship to the state, enables the author to look critically into the evolving ways in which the state has been forced to respond to the movement.

Villalón's study has great documentary value. It gives new facts about the evolving structures of Senegalese society. Particularly interesting are the roles that ethnicity, caste, language, and religion play in the shaping of Senegalese society. Accordingly, the study features many informative tables on the following subjects: Senegalese ethnic groups by census categories; ethnic composition of Senegal and Fatick; speakers of principal Senegalese languages as either a first or second language; and the religious composition of both Senegal (c. 1960) and Fatick (1988). 
Traditional scholarship on the Senegalese Sufi orders has focused on the most studied of them, the Mouride order. Villalón's work is a comprehensive study of the old, the disbanded, and the emerging orders. Also, the study provides a much-needed update on the evolving role of Islam in Senegal. This information is particularly needed, as virtually nothing of note has been written on this subject since the 1979 Iranian Revolution.

The study also has a revisionist, if not polemical contribution to scholarship. It debunks or lends nuance to many tenured ideas on the power of the marabouts in Senegal. Beyond charisma, argues Villalón, one needs to consider more concrete incentives that maintain long-term ties between the marabouts and their tälibées. The author departs from the long-held position that presents the marabouts as figures of unquestionable authority. Rather, he views them as "important individuals whose good position in the network of affective ties grants them a greater degree of leverage over the state than is otherwise available to individuals in society" (p. 124).

Without denying an element of inequality in the relationship between the marabouts and their followers, the book presents the concrete socioeconomic appeals of the orders for the Senegalese people and questions the vision of masses blindly manipulated by a religious elite. Consequently, cautions the writer, the activities of the Daaras (local chapters of religious organizations) should not be seen as signs of the much discussed world-wide Islamic revival; rather, these activities must be seen in the context of the concrete appeals that religious organizations have.

Villalón's work is a valuable contribution to the study of Senegal, African politics, and Islam's role in it. His very detailed account of life in a contemporary African town will be of great interest to sociologists and anthropologists. His descriptions and theoretically based analysis of the Senegalese state's efforts to bring its traditionalist citizenry into the fold of the modern nation-state will interest both political scientists and active participants. Finally, it is refreshing to see an analysis of Islam as an element of political stability. Villalón provides a sound explanation for this rather interesting situation, an explanation that holds much relevance for anyone interested in the subject of the political roles of Islam.

Ahmed Sheikh Bangura Department of Modern and Classical Languages University of San Francisco San Francisco, California 